\title{
SEKOLAH RAMAH ANAK \\ ERA REVOLUSI INDUSTRI 4.0 \\ DI SD MUHAMMADIYAH PAJANGAN 2 BERBAH \\ YOGYAKARTA
}

\begin{abstract}
Ahmad Tarmizi Hasibuan, Rahmawati
Universitas Islam Negeri Sunan Kalijaga Yogyakarta

Jl. Marsda Adisucipto, Yogyakarta 55281

Email: roszi0508@gmail.com,rahmazahra2705@gmail.com
\end{abstract}

\begin{abstract}
ABSTRAK
Tujuan penelitian ini adalah mengungkapkan upaya Sekolah Dasar (SD) Muhammadiyah Pajangan 2 Berbah dalam mewujudkan Sekolah Ramah Anak (SRA) dalam era revolusi industri 4.0. Penelitian ini mengambil lokasi di SD Muhammadiyah Pajangan 2 Berbah Yogyakarta. Penelitian ini merupakan penelitian kualitatif yang menggunakan pendekatan fenomenologis. Dalam pengumpulan data, peneliti menggunakan metode triangulasi (wawancara mendalam, observasi, dan dokumentasi) dan membaca buku-buku terkait. Penelitian ini menemukan bahwa untuk mewujudkan sekolah ramah anak era revolusi industri 4.0, SD Muhammadiyah Pajangan 2 Berbah menerapkan. 6M, yaitu: 1) Membudayakan 5S (salam, senyum, sapa, sopan dan santun), 2) menanamkan nilai-nilai ikrar Muhammadiyah, 3) meningkatkan pembiasaan (Riyadhoh), 4) meningkatkan sarana prasarana, 5) meningkatkan mutu pendidik, dan 6) meniadakan kantin sekolah.
\end{abstract}

\section{Kata Kunci: Era Revolusi Industri 4.0, Sekolah Dasar, Sekolah Ramah Anak}

\section{ABSTRACT}

The purpose of this study was to reveal the efforts of the Muhammadiyah Elementary School (ES) of Pajangan 2 in realizing child friendly schools (CFS) in the era of industrial revolution 4.0. This study took place at Muhammadiyah Elementary School of Pajangan 2, Berbah, Yogyakarta. This research is a qualitative research that uses a phenomenological approach. In collecting data, researchers used the trianggulation method (in-depth interviews, observations, and documentation) and read related books. This study found that to realize child-friendly schools in the industrial 
revolution era 4.0, SD Muhammadiyah Pajangan 2 Berbah applied. 6M, namely: 1) Cultivating $5 S$ (greetings, smiles, greetings, courtesy and courtesy), 2) instilling the values of Muhammadiyah pledges, 3) increasing habituation (Riyadhoh), 4) improving infrastructure, 5) improving the quality of educators, and 6) stop the school canteen.

\section{Keywords: Era of Industrial Revolution 4.0, Elementary School,} Child Friendly Schools.

\section{A. PENDAHULUAN}

Pendidikan merupakan wadah awal dalam memulai proses belajar. Wadah atau tempat yang menaungi pendidikan biasanya disebut dengan lembaga. Lembaga terdiri dari pendidikan formal maupun non formal. ${ }^{1}$ Pendidikan formal biasanya terdiri dari Taman Kanak-Kanak (TK), Sekolah Dasar (SD) atau Madrasah Ibtidaiyah (MI), Sekolah Menengah Pertama (SMP) atau Madrasah Tsanawiyah (MTS), Sekolah Menengah Atas (SMA) atau Madrasah Aliyah (MA) dan Sekolah Kejuruan. Sedangkan pendidikan non formal biasanya lebih menekankan pada aspek pengembangan seperti les atau privat. Pendidikan di Indonesia sudah mengalami beberapa perubahan sistem dalam penerapannya seperti perubahan kurikulum, dari KTSP hingga menjadi Kurikulum 2013. ${ }^{2}$ Tindakan atau perubahan ini dilakukan bukan menjadi bahan cobaan pemerintah, namun dilakukan perubahan ini sesuai dengan perkembangan zaman. Perkembangan di sini adalah perkembangan pendidikan yang sudah memasuki era keterbukaan atau era

\footnotetext{
${ }^{1}$ Yusrizal, Intan Safiah, and Nurhaidah, "Kompetensi Guru Dalam Memanfaatkan Media Pembelajaran Berbasis Teknologi Informasi Dan Komunikasi (TIK) Di SD Negeri 16 Banda Aceh," Jurnal Ilmiah Pendidikan Guru Sekolah Dasar FKIP Unsyiah 2, no. 2 (2017): 126-134.

2 Azyumardi Azra, Pendidikan Islam Tradisi dan Modernisasi di Tengah Tantangan Milenium III, 1st ed. (Jakarta: Kencana, 2012), hlm. 5. 
globalisasi. Era keterbukaan atau era globalisasi ditandai dengan mudah mendapatkan informasi melalui media atau teknologi. Teknologi dalam abad era globalisasi sering disebut dengan era digital atau era revolusi industri 4.0 yang mengharapkan sumber daya manusia berkualitas atau memiliki keterampilan.

Era revolusi industri 4.0 menjadi tantangan atau hambatan bagi suatu lembaga namun sebaliknya mampu menjadi pembantu dalam menciptakan intelektual yang cerdas demi mewujudkan citacita bangsa yaitu membelajarkan manusia. ${ }^{3}$ Menjadikan manusia pembelajar bukan hal mudah seperti membalikkan telapak tangan. Oleh karenanya, lembaga yang sukses adalah lembaga yang mampu menyeimbangkan pendidikan dengan perkembangan zaman. Mengembangkan pendidikan dalam abad keterbukaan (century of opennes) bukan perkara mudah seperti memberikan inspirasi. Demikian perlu penginovasian untuk menyetarakan antara pendidikan era revolusi industri 40 dengan karakter.

Akhir-akhir ini sering terjadi kasus kekerasan terhadap anak termasuk di sekolah. Berdasarkan penelitian beberapa daerah di Indonesia yang dilakukan oleh UNICEF membuktikan bahwa sekitar $80 \%$ masih rawan kekerasan di lingkungan sekolah yang dilakukan pendidik kepada siswa. ${ }^{4}$ Perihal ini sangat mengejutkan oleh para ahli pendidikan. Dalam tataran pendidikan, sekolah seharusnya menjadi tempat aman bagi anak didik. Namun realita

\footnotetext{
3 Imam Abdul Syukur, "Profesionalisme Guru Dalam Mengimplementasikan Teknologi Informasi Dan Komunikasi Di Kabupaten Nganjuk," Jurnal Pendidikan Dan Kebudayaan 20, no. 2 (2014): 200-210.

4 Sukaca Bertiani and Hariwijaya, PAUD: Melejitkan Potensi Anak Dengan Pendidikan Sejak Dini (Yogyakarta: Mahadika Publishing, 2009), hlm. 15.
} 
yang terjadi di beberapa sekolah masih banyak kekerasan yang dilakukan pendidik terhadap siswa di lingkungan sekolah.

Kekerasan terhadap anak tidak hanya terjadi di lingkungan sekolah, namun dalam keluarga sekalipun dapat terlihat dari beberapa kasus-kasus seperti kekerasan dalam rumah tangga (KDRT) dan selalu anak menjadi korban. Kejadian ini akan mengakibatkan penurunan karakter pada anak, seperti anak akan keras kepala atau berkarakter keras, pemarah, bahkan akan acuh tak acuh dalam melakukan sesuatu. Oleh karena itu, perlu dilakukan penginovasian dalam suatu lembaga termasuk sekolah.

Pendidikan di sekolah seharusnya menerapkan serta mengembangkan pembelajaran humanistik yang menekankan penciptaan suasana belajar yang nyaman dan menyenangkan dengan memperhatikan dan mengkolaborasikan potensi yang dimiliki anak sesuai dengan perkembangan fisik dan psikis jiwa. ${ }^{5}$ Bukan hanya di sekolah, di dalam lingkungan masyarakat harus mampu mengutamakan kasih sayang yang mengedepankan kenyamanan dan perlindungan terhadap anak.

Hal ini selaras dengan Undang-undang No. 23 Pasal 54 Tahun 2002 tentang perlindungan anak yang menyatakan bahwa:

"Anak wajib dilindungi dari berbagai tindakan kekerasan yang sering dilakukan dalam lingkungan masyarakat (orangtua) dan sekolah (guru, dan pengelola sekolah) serta lembaga pendidikan yang bersangkutan (formal dan non formal), agar mampu menciptakan ketenangan dan

\footnotetext{
${ }^{5}$ Kholid Musyaddad, "Problematika Pendidikan Di Indonesia," Journal Education and Biology 4, no. 1 (2013).
} 
kenyamanan demi mewujudkan sumber daya manusia yang berkualitas sesuai dengan tujuan pendidikan. ${ }^{6}$

Berdasarkan pengertian di atas, disimpulkan bahwa anak memiliki hak untuk hidup tumbuh, berkembang dan berpartisipasi secara wajar sesuai dengan harkat, martabat manusia serta harus mendapatkan perlindungan dari kekerasan atau diskriminasi orang dewasa (guru dan lapisan masyarakat). Untuk merealisasikan undang-undang di atas maka diperlukan inovasi baru, yaitu dengan sekolah ramah anak (SRA), yang diharapkan mampu menciptakan suasana belajar yang nyaman dan tenang untuk mampu mengembangkan minat, bakat serta potensi yang dimilki anak didik sesuai dengan perkembangan dan pertumbuhan era revolusi industri 4.0 .

Sekolah Ramah Anak (SRA) merupakan inovasi terbaru yang dikeluarkan oleh pemerintah untuk mengefektifkan proses pembelajaran. ${ }^{7}$ Dalam tataran pendidikan, menciptakan suasana belajar ramah anak tidak mudah, karena sekolah harus memiliki indikator-indikator yang harus dipenuhi, agar dapat pengakuan sebagai sekolah ramah anak. Sekolah ramah anak harus diterapkan pada pendidikan awal terlebih dahulu, karena pendidikan dasar akan menjadi penentu nantinya dalam pendidikan selanjutnya yang sesuai dengan perkembangan dan pertumbuhan anak.

Setidaknya ada beberapa hal yang harus dipahami dalam mewujudkan sekolah ramah anak yaitu: Anak terlibat aktif dalam

\footnotetext{
${ }^{6}$ Presiden Republik Indonesia, Undang-Undang No. 23 Tahun 2002 Tentang Perlindungan Anak, 2007.

${ }^{7}$ Misnatun, "Pola Pembentukan Karakter Anak Melalui Pendidikan Ramah Anak Dalam Perspektif Pendidikan Islam," Tadarus: Jurnal Pendidikan Islam 5, no. 2 (2006): 1-19.
} 
memecahkan masalah yang berkaitan dengan masa depannya, keluarga dan lingkungan sekitar, memberikan hak-hak anak dalam menopang perkembangan dan pertumbuhan untuk mengembangkan potensinya, memberi ruang bagi anak dengan cara mengadakan sarana prasarana untuk bermain, berinteraksi serta berkreasi dengan teman-teman sejawatnya dan guru harus mampu menjamin kenyamanan, serta menanamkan menghargai perbedaan pendapat (ras, suku, budaya dan agama). Sedangkan dalam pendidikan Islam, pendidikan ramah anak lebih berfokus pada ikatan cinta dan kasih sayang yang mengedepankan kebersamaan bukan perkelahian.

SD Muhammadiyah Pajangan 2 Berbah Sleman adalah salah satu dari sekian ratus sekolah dasar di Daerah Istimewa Yogyakarta. Sekolah ini memiliki keunikan, yang berbeda dengan sekolahsekolah pada umumnya. SD Muhammadiyah Pajangan 2 Berbah memiliki visi sebagai sekolah yang ramah anak. Berdasarkan berbagai pertimbangan tersebut, penelitian ini berusaha mengungkap dan menganalisis upaya Sekolah Dasar (SD) Muhammadiyah Pajangan 2 Berbah dalam mewujudkan Sekolah Ramah Anak (SRA) dalam era revolusi industri 4.0.

\section{B. METODE PENELITIAN}

Penelitian ini menggunakan pendekatan kualitatif dengan metode studi kasus. Pengumpulan data penelitian memakai metode observasi, wawancara dan dokumentasi. Dalam praktiknya, peneliti mengecek keabsahan data dengan teknik triangulasi. Obyek material penelitian ini adalah SD Muhammadiyah Pajangan 2 Berbah Sleman Yogyakarta. Sementara itu, informan penelitiannya terdiri dari 
kepala sekolah, pendidik, orangtua dan anak didik. Informan dipilih menggunakan teknik purposive sampling.

\section{HASIL PENELITIAN DAN PEMBAHASAN}

Sekolah merupakan kunci sukses dalam mewujudkan sumber daya manusia. Sumber daya manusia yang dimaksud bukan sumber daya manusia biasa namun berkualitas. Kualitas anak didik akan terlihat apabila pendidik mampu menciptakan suasana belajar yang nyaman dan tenang yang mengedepankan hak-hak anak, agar dapat bersaing di era revolusi industri 4.0 selaras dengan tujuan pendidikan nasional. Untuk mewujudkan sekolah ramah anak SD Muhammadiyah Pajangan 2 Berbah sudah mulai berbenah dengan cara mengupayakan beberapa kegiatan, seperti menerapkan sistem 6M, yaitu: membudayakan 5S (salam, senyum, sapa, sopan dan santun), menanamkan nilai-nilai ikrar muhammadiyah, meningkatkan pembiasaan (riyadhoh), meningkatkan sarana prasarana, meningkatkan pendidik yang bermutu dan berkualitas, dan meniadakan kantin sekolah. Penjelasan selengkapnya diuraikan sebagai berikut:

\section{Membudayakan 5 S (Salam, Senyum, Sapa, Sopan Dan Santun)}

Berbicara pendidikan bukan hanya menjelaskan bagaimana membimbing, mengajar dan melatih namun bagaimana membudayakan kebaikan. ${ }^{8}$ Membudayakan suatu kebaikan bukan perkara mudah dalam suatu lembaga atau sekolah. Sekolah yang notabennya menjadi wadah bagi manusia

\footnotetext{
${ }^{8}$ Sudjarwo S., Teknologi Pendidikan (Jakarta: Erlangga, 2011), hlm. 50.
} 
dituntut untuk lebih mengedepankan kenyamanan dalam berinteraksi. Interaksi akan terlihat baik, bila feedback yang didapatkan bagus. ${ }^{9}$ Oleh karenanya tugas pendidik bukan hanya menjadi pendidik, pengajar dan pelatih, namun pendidik harus lebih memahami karakteristik anak didiknya terutama dalam berinteraksi.

Interaksi yang baik, diharapkan dapat menjawab tantangan dalam abad yang dikenal dengan era pengetahuan (knowledge age), sehingga mampu menciptakan sumber daya manusia (peserta didik) berkualitas yang mampu bersaing dalam era keterbukaan. ${ }^{10}$ Maksudnya pendidik harus mampu berinteraksi atau berkomunikasi secara baik, demi menciptakan suasana belajar dalam lingkungan sekolah tidak terkecuali pada masa sekarang yang dikenal dengan era revolusi industri 4.0. Revolusi industri 4.0 ditandai dengan perkembangan teknologi, sehingga memudahkan siswa dalam mencari informasi dan pengetahuan. ${ }^{11}$ Informasi dan pengetahuan melebur begitu cepat dalam ajang yang meminta kualitas sumber daya manusia, sehingga peran pendidik akan bergeser yang dulunya menjadi tempat bertanya segala sesuatu, sedikit banyaknya akan melebur

\footnotetext{
${ }^{9}$ Nurdin Mansur, "Penerapan Keterampilan Mengajar Dalam Upaya Pencapaian Hasil Belajar Mahasiswa," Lantanida Journal 4, no. 2 (2016): 118-127.

10 A. Sudriarja, Pendidikan Dalam Tantangan Zaman (Yogyakarta: Kanisius, 2014), hlm. 3.

${ }^{11}$ Etistika Yuni Wijaya, Dwi Agus Sudjimat, and Amat Nyoto, "Transformasi Pendidikan Abad 21 Sebagai Tuntutan Pengembangan Sumber Daya Manusia Di Era Globalisasi," in Prosiding Seminar Nasional Pendidikan Matematika 2016, vol. 1 (Malang: Universitas Kanjuruhan Malang, 2016), 263-278, http://repository.unikama.ac.id/840/32/263-278 TRANSFORMASI PENDIDIKAN ABAD 21 SEBAGAI TUNTUTAN PENGEMBANGAN SUMBER DAYA MANUSIA DI ERA GLOBAL.pdf. diakses pada; hari/tgl; sabtu, 3 November 2018. jam; 00:26, wib.
} 
dalam dimensi "ruang dan waktu", sehingga tugas pendidik akan menjadi begitu berat untuk menciptakan suasana belajar yang nyaman.

Pembelajaran yang nyaman dan tenang akan terlihat ketika pendidik berperan aktif dalam proses pembelajaran untuk mewujudkan tujuan pendidikan nasional. ${ }^{12}$ Tujuan pendidikan nasional bukan bermuara untuk saat ini, akan tetapi lebih menekankan dalam memproduksi sumber daya manusia yang mampu bersaing dalam ajang dunia keterampilan untuk masa yang akan datang. Era revolusi industri 4.0 merupakan ajang yang sangat meminta kualitas baik dalam menguasai teknologi maupun kemampuan lain yang masih dalam ranah digital.

Oleh karenanya, SD Muhammadiyah Pajangan 2 Berbah ingin mewujudkan sekolah ramah anak dalam tantangan revolusi industi 4.0 yang meminta kualitas anak didik. Mewujudkan sekolah ramah anak dengan cara membudayakan salam, senyum, sapa, sopan dan santun atau disebut dengan $5 \mathrm{~S}$. Membudayakan $5 \mathrm{~S}$ sangat dianjurkan kepala sekolah Muhammadiyah Pajangan 2 Berbah, untuk dapat memberi pendekatan khusus bagi anak didik agar pendidik tidak selalu miring dipandang oleh peserta didik.

Pernyataan di atas sesuai dengan penuturan kepala sekolah yang menyatakan bahwa:

"Pemimpin harus dapat menyesuaikan perkembangan teknologi dengan cara menginovasinya. Inovasi yang dapat membuat anak didik nyaman dan tenang, salah

12 Ibrahim Bafadal, Peningkatan Profesionalisme Guru MI Dalam Manajemen Mutu Berbasis Madrasah (Jakarta: Bumi Aksara, 2004), hlm. 3. 
satunya dengan cara mewujudkan sekolah ramah anak. Sekolah ramah anak akan membuat hak-hak anak tersalurkan dan merasakan proses pembelajaran yang nyaman dan tenang sesuai dengan pertumbuhan dan perkembangannya. Menyikapi sekolah ramah anak, saya dan pendidik-pendidik menggunakan cara tersendiri dalam mewujudkannya, yaitu dengan cara membudayakan salam, senyum, sapa, sopan dan santun yang sering disingkat dengan sebutan $5 \mathrm{~S}$. Awalnya saya menerapkannya di sekolah saya dahulu sebelum dipindahkan di sini, perilaku ini saya harapakan mampu mewujudkan sekolah ramah anak terkhusus SD Muhammadiyah Pajangan 2 Berbah. ${ }^{13}$

Proposisi di atas menggambarkan begitu seriusnya sikap kepala sekolah dalam menyikapi era keterbukaan atau era globalisasi. Era globalisasi sejatinya menuntut anak lebih berkompeten atau dengan kata lain, lebih menekankan pada kualitas. Oleh karenanya, pendidik harus dapat menunjukkan kualitasnya sebagai pendidik, sehingga dalam proses pembelajaran memudahkan anak didik dalam memahami pelajaran.

Hal ini senada dengan pernyataan wali kelas IV-A yang menyatakan bahwa:

"Masa sekarang sudah terkena virus teknologi dengan
alat yang sangat sering digunakan dalam kehidupan
sehari-hari yaitu handphone. Handphone sudah menjadi
kecanduan dalam tataran kehidupan, sehingga dapat
mengubah kebiasaan dalam kehidupan. Kehidupan
sekarang sudah menjadikan manusia lebih canggih.
Maksudnya manusia harus lebih serius dalam
menggunakan teknologi, bila tidak mau tergelincir di
dalamnya. Pendidik yang tugas awalnya mendidik,
mengajar, dan melatih harus mampu menyesuaikan

13 Wawancara dengan Kepala Sekolah tanggal 21 Januari 2019 di SD Muhammadiyah Pajangan 2 Berbah Yogyakarta. 
keadaan yang ada agar memudahkannya dalam mengkoneksikan segala ilmu, sehingga tidak menjadi hambatan yang ditakutkan oleh pendidik. Untuk itu, kepala sekolah sekarang mengajarkan kepada pendidikpendidik untuk lebih bercengkrama bersama antara pendidik dan anak didik dengan membudayakan salam, senyum, sapa, sopan dan santun, agar mampu mewujudkan sekolah ramah anak yang berkompeten dan mampu bersaing dalam era teknologi. ${ }^{14}$

Pendapat di atas diperkuat oleh pernyataan orangtua selaku komite sekolah yang menyatakan bahwa:

"Pendidikan sekarang bermuara pada perkembangan ilmu teknologi. Murahnya teknologi memudahkan para orangtua untuk memberikan kepada anak tidak terkecuali handphone (Hp) yang membuat hati anak senang bila memilikinya, sudah memilki inovasi terbaru di dalam pengaplikasiannya yang hampir rata-rata sudah layar sentuh. Penggunaan teknologi memiliki dua kemungkinan yaitu positif dan negatif. Positif apabila orangtua mampu mengontrol anak dalam menggunakanya. Dengan kata lain orangtua harus membatasi anak dalam penggunaan teknologi. Sedangkan penggunaan teknologi akan menjadi negatif bila orang tua tidak mengontrol anak secara serius, anak akan melihat serta melakukan perilaku yang tidak sesuai dengan perkembangan dan pertumbuhannya. Melihat perkembangan yang begitu cepat, saya sebagai orangtua setuju dengan pernyataan kepala sekolah yaitu membuat sekolah SD pajangan 2 berbah menjadi sekolah ramah anak yang bernuansa Islami dengan cara membudayakan $5 \mathrm{~S}$ yaitu salam, senyum, sapa, sopan dan santun atau lebih tepatnya $5 \mathrm{~S}$. Membudayakan 5S diharapkan dapat memudahkan pendidik dalam berintraksi sehingga memiliki kedekatan khusus untuk memudahkan dalam

14 Wawancara dengan Wali Kelas IV-A tanggal 21 Januari 2019 di SD Muhammadiyah Pajangan 2 Berbah Yogyakarta. 
penyampain materi serta anak didik mampu dengan mudah memahami isi materi secara cepat."

Proposisi di atas dapat diambil kesimpulan bahwa keinginan kepala sekolah, pendidik dan orangtua sangat besar dalam menciptakan sekolah ramah anak yang mampu membentuk anak didik yang cerdas selaras dengan pertumbuhan dan perkembangan serta diharapkan mampu bersaing di era revolusi industri 4.0 yang mengedepankan kualitas sumber daya manusia. Membentuk sumber daya manusia bukan perkara mudah, oleh karenanya peran kepala sekolah, pendidik dan orangtua harus sesuai dengan perkembangan zaman yang sering disebut dengan era revolusi industri 4.0. Agar dapat mewujudkan sekolah ramah anak, kepala sekolah, pendidik dan orangtua harus mampu menghargai hak-hak anak, agar terciptanya suasana belajar yang nyaman dan tentram.

Demi mewujudkan sekolah ramah anak, SD Muhammadiyah Pajangan 2 Berbah harus mampu mengoptimalkan cara yaitu dengan membudayakan 5S. Agar dapat mewujudkan sekolah ramah anak dalam era industri 4.0, SD Muhammadiyah Pajangan 2 Berbah harus lebih giat menjalankan tugas terutama kepala sekolah, pendidik dan orangtua untuk membudayakan salam, senyum, sapa, sopan dan santun atau sering disebut dengan 5S. Dengan upaya ini, SD Muhammadiyah Pajangan 2 Berbah diharapkan mampu mewujudkan sekolah ramah anak dalam era revolusi industry

15 Wawancara dengan Komite Sekolah tanggal 21 Januari 2019 di SD Muhammadiyah Pajangan 2 Berbah Yogyakarta. 
4.0 yang dapat menghargai hak-hak anak didik demi menciptakan suasana belajar yang nyaman dan tenang serta mampu membentuk anak didik yang berkualitas sesuai dengan tantangan zaman.

\section{Menanamkan Nilai-nilai Ikrar Muhammadiyah}

SD Muhammadiyah Pajangan 2 Berbah adalah sekolah yang menjunjung tinggi janji atau ikrar. Janji atau ikrar yang dimaksud merupakan suatu perkara yang selalu diucapkan anak didik setelah berdo'a dan sebelum memulai pelajaran. Sebelum memulai pelajaran pihak sekolah mengupayakan untuk menanamkan ikrar muhammadiyah. Pihak sekolah berusaha mewujudkan yang terbaik untuk menjadikan anak didiknya benar-benar dapat menjadi generasi yang dibanggakan, agar mampu bersaing di era revolusi industri 4.0. Sekolah berupaya menjunjung tinggi dan terus-menerus berusaha melaksanakan ikrar Muhammadiyah, agar tertanam dalam jiwa anak didik sebagai wujud penghormatan serta pengamalan anak didik, bahkan anak didik akan melafadzkan ikrar Muhammadiyah sebelum melakukan belajar di kelas, maka anak didik SD Muhammadiyah Berbah diwajibkan untuk hafal (to memorized) ikrar Muhammadiyah ini.

Adapun Ikrar/Janji pelajar muhammadiyah diantaranya: Pertama berjuang menegakkan ajaran Islam sesuai dengan AlQuran dan Al-Hadist dan Ijtima para mujtahid Muhammadiyah, Kedua hormat dan patuh terhadap orangtua dan pendidik tanpa membantah atau membangkang perkataan dan perintah keduanya, Ketiga bersungguh-sugguh dalam menuntut ilmu 
untuk mewujudkan bangsa yang cerdas, Keempat bekerja keras, mandiri dan berprestasi dalam menjalankan tugas sebagai anak didik, Kelima rela berkorban dan menolong sesama teman dalam mewujudkan ketentraman dan kenyamanan bersama, dan Keenam siap menjadi kader Muhammadiyah dan bangsa yang berbudi luhur sesuai dengan tuntutan Muhammadiyah.

Melafalkan dan menghafalkan ikrar ini bertujuan agar anak-anak SD Muhammadiyah Pajangan 2 Berbah dapat menekuni, mengingat juga, serta mengamalkan apa saja yang terkandung di dalamnya. Dengan upaya menanamkan ikrar Muhammadiyah sekolah berharap mampu membentuk anak didik agar menjadi generasi yang siap bersaing untuk menghadapi tantangan era revolusi industri 4.0.

Pihak sekolah sadar akan era globalisasi atau era revolusi industri 4.0, maka anak-anak sebagai generasi muda dipersiapkan untuk menghadapi era revolusi industri 4.0 tersebut. Keterampilan yang diperlukan pada era revolusi industri 4.0 atau abad 21 tersebut yang pertama adalah life and career skills yaitu keterampilan hidup dan berkarir. Anak didik diharapkan mampu menghadapi perubahan fleksibel dalam belajar dan berkegiatan dalam kelompok, menjadi anak yang disiplin, dapat bersosialisasi di sekolah ataupun masyarakat, dan menunjukkan sikap bertanggung jawab dan dapat memimpin teman-temannya. Yang kedua adalah learning and innovation skills yaitu keterampilan dalam belajar dan berinovasi, anak didik dapat menggunakan cara berpikir kritis dalam menghadapi sebuah masalah, dapat berkomunikasi dengan semua anak dan 
juga dapat bekerjasama dalam kelompok, dan mampu kreatif dan inovatif. Yang ketiga adalah informasi media and technology skills yaitu keterampilan dalam berteknologi dan media, anak didik mampu mengakses informasi secara efektif, mengelola dan menggunakan teknologi dan literasi media.

Berdasarkan tantangan yang dihadapi dalam era revolusi industri 4.0, sekolah berupaya untuk menanamkan ikrar Muhammadiyah bagi anak didik agar dapat menciptakan terbinanya anak didik yang cerdas dan beradab sesuai dengan tujuan pendidikan nasional. Adab merupakan kunci dalam mensukseskan dalam mewujudkan sekolah ramah anak yang dapat memenuhi hak-hak anak dan menciptakan suasana belajar. Untuk dapat mewujudkan sekolah ramah anak dalam menghadapi era revolusi industri 4.0, SD Muhammadiyah berupaya menanamkan nilai-nilai yang terdapat dalam ikrar Muhammadiyah.

\section{Meningkatkan Pembiasaan (Riyadhoh)}

SD Muhammadiyah Pajangan 2 Berbah adalah sekolah dasar yang berusaha untuk mewujudkan anak didiknya menjadi manusia yang berkualitas, berkarakter dan berilmu, hal ini sesuai dengan kebijakan yang telah ditetapkan oleh pihak sekolah dan semua komponen yang ada di sekolah Pajangan 2 Berbah tersebut yaitu para pendidik, para tata usaha, satpam dan semua yang ada di sekolah tersebut. Semua komponen yang ada di sekolah berpadu untuk terwujudnya generasi Islami. SD Muhammadiyah Pajangan 2 Berbah menetapkan peraturan di setiap pagi dari jam 06.50 kegiatan keagamaan yaitu 
pembiasaan atau "Riyadhah". Kegiatan tersebut di mulai dengan shalat dhuha, dzikir, membaca nama-nama Allah atau sering disebut dengan Asmaul Husna serta berdo'a yang terdiri dari do'a sholat dhuha, doa kedua orangtua dan doa belajar secara bersama-sama (antara guru anak dan anak didik). Dalam kegiatan Riyadhoh ini, pendidik menyuarakan anak didik agar memakai peralatan shalat lengkap dan akan diimami oleh salah satu anak didik, setelah itu berdzikir dan berdo'a serta membaca "asmaul husna" yang dilantunkan oleh pendidik, setelah itu adalah kegiatan menghafal surah pendek atau juz 30 dan diakhiri dengan senandung Al-Qur'an, kemudian penyetoran hafalan atau "muraja'ah" yang dilakukan anak didik di dalam kelas, untuk dilaporkan dengan wali kelas masing-masing. Semua rangkaian kegiatan dilakukan secara bersama-sama. Kegiatan pembiasaan atau "Riyadhah" ini dilakukan di lapangan sekolah yang terdiri dari kelas satu sampai dengan tiga, sedangkan anak didik kelas empat, lima dan enam dilakukan dalam musholla.

Hal ini sesuai dengan penuturan wali kelas VI -A yang menyatakan bahwa:

"Kegiatan pembiasaan atau dalam Islam sering disebut dengan riyadhah. Kegiatan ini dilakukan untuk bertujuan sebagai pembiasaan kepada anak-anak didik sendiri. Pihak sekolah atau kepala sekolah sangat berusaha dalam menanamkan kebiasaan baik untuk anak-anak, agar memudahkan anak dalam menjadikannya anak pembelajar, karena selagi masih kecil (anak didik) walau sedikit tapi pihak sekolah yakin bahwa dengan pembiasaan ini maka akan sangat berdampak baik untuk kehidupan anak-anak didik selanjutnya, untuk melanjutkan ke jenjang pendidikan 
berikutnya (Sekolah Menengah Pertama-Sekolah Menengah Atas-Perguruan Tinggi). Untuk itu dari sekarang dilakukan pembiasaan bagi anak didik, agar terwujudnya anak yang cerdas dan berkualitas tinggi serta mampu bersaing di era sekarang. ${ }^{16}$

Penuturan di atas diperkuat oleh pendapat pendidik Tahfidz Alquran yang mengatakan bahwa:

"Sejak berganti kepemimpinan atau kepala sekolah, barulah terbentuk kegiatan yang membiasakan untuk mendidik anak sesuai dengan usia pertumbuhan dan perkembangan. Pertumbuhan dan perkembangan anak didik harus diperhatikan oleh pendidik, tidak terkecuali di era sekarang yang dikenal dengan era globalisasi yang ditandai dengan perkembangan ilmu penegtahuan dan teknologi. Perkembangan ilmu teknologi membuat pendidik sadar akan tugasnya yaitu mencetak anak didik yang cerdas agar terbentuknya anak-anak yang berkualitas sesuai dengan tujuan pendidikan. Maksudnya pendidik harus memiliki pandangan kedepan dalam menciptakan suasana belajar yang nyaman dan tentram agar mampu membentuk intelektual yang cerdas sesuai perkembangan zaman. Perkembangan zaman sangat mengedepankan kualitas dari pada kuantitas. Oleh karenanya pendidik harus dapat membuat suasana belajar yang nyaman sehingga mampu mewujudkan sekolah ramah anak yang sesuai dengan zaman di era globalisasi." 17

Berdasarkan dua rangkuman wawancara di atas dapat diambil kesimpulan bahwa era globalisasi yang sering disebut dengan era revolusi industri 4.0 bertujuan mengedepankan teknologi kualitas sumber daya manusia. Oleh karenanya

16 Wawancara dengan Wali Kelas VI-A tanggal 21 Januari 2019 di SD Muhammadiyah Pajangan 2 Berbah Yogyakarta.

17 Wawancara dengan Guru Tahfidz Alquran tanggal 21 Januari 2019 di SD Muhammadiyah Pajangan 2 Berbah Yogyakarta. 
pendidik harus dapat mengenali minat, bakat dan potensi anak didik sehingga nantinya mampu mengembangkan potensipotensi yang dimiliki anak. Untuk mengembangkan potensi yang dimiliki anak-anak SD Muhammadiyah Pajangan 2 Berbah dalam mewujudkan sekolah ramah anak pada tantangan abad era revolusi industri 4.0. Era industri 4.0 ditandai dengan berkembangnya informasi yang memudahkan setiap orang dalam mengaksesnya melalui teknologi. Teknologi yang memudahkan segala cara dalam mendapatkan sesuatu, sangat membantu manusia dalam berinteraksi dan berkerjasama.

Era revolusi industri 4.0 sangat erat kaitannya dan ditandai dengan perkembangan ilmu teknologi. Perkembangan teknologi dapat menjadi hal positif dan negatif, tergantung pendidik dan anak didik dalam menyikapinya. Oleh karenanya untuk menghadapi era revolusi industri 4.0, SD Muhammadiyah Pajangan 2 Berbah ingin mewujudkan sekolah ramah anak dengan cara meningkatkan pembiasan (riyadhoh), dengan cara membiasakan sholat dhuha, berdzikir, berdo'a, menghafal Asmaul Husna dan surah pendek dalam Al-Qur'an yang diharapkan mampu memberikan hak-hak anak didik sepenuhnya serta mampu mewujudkan sekolah yang berkarakter sesuai dengan karakter yang diinginkan bangsa dan negara.

\section{Meningkatkan Sarana Prasarana}

Dalam tataran pendidikan, sekolah harus mampu menciptakan suasana belajar yang baik, salah satu caranya 
dengan cara meningkatkan sarana prasarana. ${ }^{18}$ Sarana prasarana merupakan kunci awal dalam mewujudkan sekolah ramah anak, karena dengan sarana prasarana akan tercipta suasana yang mengedepankan hak-hak anak dalam proses belajar mengajar. Prinsip ini merupakan cara yang harus dilakukan lembaga untuk mewujudkan sekolah ramah anak, karena tanpa sarana pendidik tidak akan mampu membentuk anak-anak cerdas selaras dengan tujuan pendidikan yang sesuai dengan perkembangan era globalisasi atau era hoppenes dan sering disebut era revolusi industri 4.0 yang ditandai dengan perkembangan ilmu pengetahuan dan teknologi.

Hal ini senada dengan penuturan wali murid atau orangtua yang melihat kondisi keadaan masyarakat saat ini yang menyatakan bahwa SD Muhammadiyah Pajangan 2 Berbah seharusnya sudah mampu mewujudkan sekolah ramah anak, disebabkan sekolah sudah memiliki beberapa sarana prasarana yang memadai, seperti bangunan sekolah, tataran kelas dan lingkungan yang nyaman, sejuk serta tenang. Sedangkan dalam pelayanan kepada orangtua, pihak sekolah sudah cukup baik yang menyediakan tempat duduk atau waiting room bagi orangtua yang ingin menjemput anaknya. Sarana prasarana yang baik diharapkan mampu menjadi ciri khas bagi sekolah dalam menyikapi beberapa ketakutan orangtua di era globalisasi yang dilihat dan ditandai dengan mudahnya mengakses segala ilmu pengetahuan dan teknologi.

18 Didin Kurniadin and Imam Machali, Manajemen Pendidikan: Konsep Dan Prinsip Pengelolaan Pendidikan (Yogyakarta: Ar-Ruzz Media, 2014). 
Perkembangan ilmu pengetahuan dan teknologi sangat mementingkan output atau lebih menekankan kualitas sumber daya manusia. Dengan sumber daya manusia diharapkan mampu mewujudkan sekolah ramah anak yang selaras dengan perkembangan era teknologi. ${ }^{19}$ Untuk menghadapi era teknologi manusia harus mempunyai sarana prasarana yang memadai dalam mengembangkan potensi yang ada, demi tercapainya pembelajaran. Pembelajaran yang baik akan memudahkan anak didik untuk memahami ilmu yang diraih atau didapatkan. Oleh karenanya, pendidikan bukan hanya berbicara soal kualitas sumber daya manusia, karena jika sumber daya manusia yang berkualitas harus ditopang oleh sarana prasarana yang memadai, tanpa sarana prasarana pendidik tidak akan mampu menciptakan suasana belajar yang nyaman serta tidak akan mampu membentuk anak berkualitas tinggi sesuai dengan tuntutan zaman era industri 4.0.

Era industri 4.0 diharapkan bukan menjadi hambatan bagi pendidik untuk mengembangkan potensi anak didik. ${ }^{20}$ Untuk itu, kepala SD Muhammadiyah Pajangan 2 Berbah sangat mengupayakan terwujudnya sekolah ramah anak, agar mampu memberikan hak-hak anak demi terciptanya intelektual cerdas dan berkualitas dengan cara meningkatkan sarana prasarana yang memadai, agar mampu memberikan hak-hak anak didik dan menciptakan suasana belajar yang nyaman dan tenang.

\footnotetext{
19 John Furlong and Chris Davies, "Young People, New Technologies and Learning at Home: Taking Context Seriously," Oxford Review of Education 38, no. 1 (2012), https://doi.org/10.1080/03054985.2011.577944.

${ }^{20}$ Furlong and Davies.
} 


\section{Meningkatkan Pendidik yang Bermutu dan Berkualitas}

Mutu adalah kualifikasi yang akan menentukan arah pendidikan wabil khusus dalam lembaga. Lembaga yang baik akan terihat dengan sarana prasarana yang baik, namun juga harus ditopang oleh pendidik yang bermutu dan berkualitas. ${ }^{21}$ Kualitas pendidik terlihat ketika mampu menciptakan suasana belajar yang diminati oleh anak didik. Anak didik adalah pembelajar yang ingin terus belajar dan terus belajar, agar tertanamnya kesadaran dalam belajar untuk terbinanya insan akademis. Untuk membentuk pembelajar atau terbinanya terciptanya anak-anak yang cerdas diperlukan pendidik yang bermutu dan berkualitas sesuai dan selaras dengan perkembangan era industri 4.0 yang menuntut persaingan dan kualitas sumber daya manusia.

Sumber daya manusia notabene-nya sangat diperlukan dalam mewujudkan bangsa yang cerdas serta bermutu dan berkualitas yang diharapkan mampu bersaing dalam era globalisasi. $^{22}$ Era globalisasi sangat dikenal dengan era keterbukaan ditandai dengan mudahnya mengakses informasi dan sangat pesat berkembangnya ilmu teknologi sehingga memudahkan pendidik dan anak didik dalam mengolah informasi. Untuk mewujudkan mutu pendidikan yang baik diperlukan pendidik yang bermutu dan berkualitas, sehingga nantinya mampu mewujudkan anak didik yang cerdas serta

\footnotetext{
21 Ace Suryadi, Pendidikan, Investasi SDM, Dan Pembangunan (Jakarta: Balai Pustaka, 2002), hlm. 31.

${ }^{22}$ Mangkunegara A.P., Perencanaan Dan Pengembangan Sumber Daya Manusia (Bandung: Refika Aditama, 2011), hlm. 37.
} 
mampu bersaing dalam era yang menuntut keahlian dan keterampilan. Dengan adanya keahlian dan keterampilan, sangat memudahkan anak didik nantinya dalam menjalankan fungsinya sebagai manusia. Oleh karenanya tugas guru seharusnya lebih meningkatkan sumber daya manusia sesuai dengan perkembangan zaman.

Sumber daya manusia atau pendidik diharapkan mampu menjadi pondasi awal dalam mewujudkan sekolah ramah anak, untuk mampu memberikan hak-hak anak selaras dengan tujuan pendidikan serta dengan perkembangan era revolusi industri 4.0 atau era keterbukaan (hoppeness era). Era keterbukaan merupakan kunci awal bagi para ahli atau pendidik untuk belajar demi mewujudkan mimpi tak terkecuali bagi anak didik sendiri. Anak didik akan mudah memahami materi, jika pendidik mampu melihat potensi yang ada di dalam dirinya serta mengembangkan potensi yang dimiliki. Oleh karenanya tugas pendidik bukan hanya mendidik namun lebih dari pada membentuk anak yang cerdas, bermutu dan berkualitas sesuai dengan perkembangan dan tantangan zaman.

Kepala SD Muhammadiyah Pajangan 2 Berbah sangat memahami bagaimana tantangan perkembangan teknologi atau era revolusi industri 4.0. Oleh karenanya kepala sekolah mengupayakan peningkatan pendidik yang bermutu dan berkualitas dengan cara memfasilitasi pendidik dan memberikan pelatihan pada para pendidik, untuk mewujudkan sekolah ramah anak (SRA) dalam lingkungan SD Muhammadiyah Pajangan 2 Berbah, agar mampu memenuhi 
hak-hak anak yaitu menciptakan suasana belajar yang nyaman dan tenang.

\section{Meniadakan Kantin Sekolah}

Sekolah harus menciptakan suasana yang nyaman dan kondusif agar anak-anak didik dapat mengekspresikan segala potensinya. ${ }^{23}$ Sekolah ramah anak harus memiliki pangan yang sehat, tidak mengandung bahan-bahan yang berbahaya bagi kesehatan anak didik dengan cara seperti sekolah harus memberikan pemahaman atau pengetahuan untuk makan makanan yang baik dan memilih makanan serta snack atau jajanan sehat. Sebagai upaya mewujudkan sekolah ramah anak, SD Muhammadiyah Pajangan 2 Berbah melakukan atau merubah beberapa sistem yang sudah ada, seperti kepala sekolah membuat kebijakan kepada anak-anak, agar tidak boleh makan atau jajan sembarangan. Untuk menunjang kegiatan tersebut maka pihak sekolah membuat program yang sesuai yaitu pihak sekolah bekerjasama dengan orang luar untuk membuat snack untuk makanan pagi hari dan siang bagi anak didik, dengan tujuan agar anak-anak makan makanan yang tidak membahayakan tubuh yang berguna bagi kesehatan.

Oleh karena itu, SD Muhammadiyah Pajangan 2 Berbah mengelola sistem makanan semua anak didik yang disebut dengan program "makan sehat". Program ini adalah kebijakan dari kepala sekolah yang didukung oleh para pendidik. Untuk

\footnotetext{
${ }^{23}$ Kristanto, Ismatul Khasanah, and Mila Karmila, "Identifikasi Model Sekolah Ramah Anak (SRA) Jenjang Satuan Pendidikan Anak Usia Dini Se-Kecamatan Semarang.," Jurnal Penelitian PAUDIA 1, no. 1 (2011): 59-74, http://dx.doi.org/10.26877/paudia.v1i1.257.
} 
menunjang program "makan sehat" tersebut maka pihak sekolah memiliki pengetahuan tentang gizi seimbang, keamanan pangan, cara mengolah pangan yang baik dan benar. Pengetahuan akan makanan sehat dan gizi seimbang sangat diperlukan dalam mengolah makanan dan menyusun menu sehari-hari sesuai dengan kebutuhan anak-anak didik sekolah dasar yang selaras dengan perkembangan dan pertumbuhan, agar anak-anak SD Muhammadiyah Pajangan 2 Berbah tercukupi kebutuhan gizinya serta mereka tidak bosan mengkonsumsi makanan sehat di sekolah dengan memperhatikan perkembangan dan pertumbuhan anak sekolah dasar. Untuk itu kebijakan kepala sekolah "tidak mentiadakan kantin" sangat diharapkan mampu tersalurkan dengan baik, agar memudahkan dalam mewujudkan sekolah ramah anak.

Kepala sekolah serta para pendidik dan komponen sekolah mempunyai peranan penting dalam mengarahkan program "makan sehat" agar bisa memperhatikan dan menyediakan makanan yang sehat, bergizi dan seimbang sesuai dengan perkembangan dan pertumbuhan anak didik. Makanan sangat penting atau salah satu yang menentukan dan berpengaruh banyak terhadap kesehatan anak didik. Maka dengan adanya program meniadakan kantin ini, diharapkan mampu mewujudkan kesadaran anak-anak didik dalam membeli snack atau makanan, agar dapat terhindar dari jajanan sembarangan atau tidak menyehatkan tubuh. Program meniadakan kantin ini diharapkan mampu mewujudkan sekolah ramah anak yang mengedepankan hak-hak anak didik, serta 
dapat menjadi suatu ciri khas tersendiri bagi SD Muhammadiyah Pajangan 2 Berbah. Upaya meniadakan kantin diharapkan mampu menjadi ciri khas SD Muhammadiyah Pajangan 2 Berbah untuk menciptakan sekolah ramah anak di era revolusi industri 4.0.

\section{SIMPULAN}

Sekolah merupakan kunci sukses dalam mewujudkan sumber daya manusia. Sumber daya manusia yang dimaksud bukan sumber daya manusia biasa namun berkualitas. Kualitas anak didik akan terlihat apabila pendidik mampu menciptakan suasana belajar yang nyaman dan tenang yang mengedepankan hak-hak anak didik, agar dapat bersaing di era revolusi industri 4.0 selaras dengan tujuan pendidikan nasional. Salah satu cara yang harus dilakukan untuk menghadapi tantangan era revolusi industri 4.0 adalah dengan menciptakan sekolah ramah anak (SRA). Untuk mewujudkan sekolah ramah anak, SD Muhammadiyah Pajangan 2 Berbah mulai berbenah dengan mengupayakan berbagai cara, seperti dengan menerapkan sistem 6M, yaitu: (1) membudayakan 5S (salam, senyum, sapa, sopan dan santun), (2) menanamkan nilai-nilai ikrar Muhammadiyah, (3) meningkatkan pembiasaan (Riyadhoh), (4) meningkatkan sarana prasarana, (5) meningkatkan pendidik yang bermutu dan berkualitas, dan (6) meniadakan kantin sekolah.

\section{E. DAFTAR PUSTAKA}

A.P., Mangkunegara. Perencanaan Dan Pengembangan Sumber Daya Manusia. Bandung: Refika Aditama, 2011. 
Azra, Azyumardi. Pendidikan Islam Tradisi Dan Modernisasi Di Tengah Tantangan Milenium III. 1st ed. Jakarta: Kencana, 2012.

Bafadal, Ibrahim. Peningkatan Profesionalisme Guru MI Dalam Manajemen Mutu Berbasis Madrasah. Jakarta: Bumi Aksara, 2004.

Bertiani, Sukaca, and Hariwijaya. PAUD: Melejitkan Potensi Anak Dengan Pendidikan Sejak Dini. Yogyakarta: Mahadika Publishing, 2009.

Furlong, John, and Chris Davies. "Young People, New Technologies and Learning at Home: Taking Context Seriously.” Oxford Review of Education 38, no. 1 (2012). https://doi.org/10.1080/03054985.2011.577944.

Kristanto, Ismatul Khasanah, and Mila Karmila. "Identifikasi Model Sekolah Ramah Anak (SRA) Jenjang Satuan Pendidikan Anak Usia Dini Se-Kecamatan Semarang.” Jurnal Penelitian PAUDIA $1, \quad$ no. $1 \quad$ (2011): 59-74. http://dx.doi.org/10.26877/paudia.v1i1.257.

Kurniadin, Didin, and Imam Machali. Manajemen Pendidikan: Konsep Dan Prinsip Pengelolaan Pendidikan. Yogyakarta: Ar-Ruzz Media, 2014.

Mansur, Nurdin. "Penerapan Keterampilan Mengajar Dalam Upaya Pencapaian Hasil Belajar Mahasiswa." Lantanida Journal 4, no. 2 (2016): 118-127.

Misnatun. "Pola Pembentukan Karakter Anak Melalui Pendidikan Ramah Anak Dalam Perspektif Pendidikan Islam.” Tadarus: Jurnal Pendidikan Islam 5, no. 2 (2006): 1-19. 
Musyaddad, Kholid. "Problematika Pendidikan Di Indonesia." Journal Education and Biology 4, no. 1 (2013).

Presiden Republik Indonesia. Undang-Undang No. 23 Tahun 2002 Tentang Perlindungan Anak, 2007.

S., Sudjarwo. Teknologi Pendidikan. Jakarta: Erlangga, 2011.

Sudriarja, A. Pendidikan Dalam Tantangan Zaman. Yogyakarta: Kanisius, 2014.

Suryadi, Ace. Pendidikan, Investasi SDM, Dan Pembangunan. Jakarta: Balai Pustaka, 2002.

Syukur, Imam Abdul. "Profesionalisme Guru Dalam Mengimplementasikan Teknologi Informasi Dan Komunikasi Di Kabupaten Nganjuk.” Jurnal Pendidikan Dan Kebudayaan 20, no. 2 (2014): 200-210.

Wijaya, Etistika Yuni, Dwi Agus Sudjimat, and Amat Nyoto. "Transformasi Pendidikan Abad 21 Sebagai Tuntutan Pengembangan Sumber Daya Manusia Di Era Globalisasi.” In Prosiding Seminar Nasional Pendidikan Matematika 2016, 1:263-278. Malang: Universitas Kanjuruhan Malang, 2016. http://repository.unikama.ac.id/840/32/263-278 TRANSFORMASI PENDIDIKAN ABAD 21 SEBAGAI TUNTUTAN PENGEMBANGAN SUMBER DAYA MANUSIA DI ERA GLOBAL.pdf. diakses pada; hari/tgl; sabtu, 3 November 2018. jam; 00:26, wib.

Yusrizal, Intan Safiah, and Nurhaidah. "Kompetensi Guru Dalam Memanfaatkan Media Pembelajaran Berbasis Teknologi Informasi Dan Komunikasi (TIK) Di SD Negeri 16 Banda 
Aceh." Jurnal Ilmiah Pendidikan Guru Sekolah Dasar FKIP

Unsyiah 2, no. 2 (2017): 126-134. 